Vol.60: e17160452, January-December 2017 http://dx.doi.org/10.1590/1678-4324-2017160452 ISSN 1678-4324 Online Edition
BRAZILIAN ARCHIVES OF BIOLOGY AND TECHNOLOGY

AN INTERNATIONAL JOURNAL

\title{
Biological Synthesis of Selenium Nanoparticles and Evaluation of their Bioavailability
}

\author{
Saeedeh Pouri ${ }^{1}$, Hossein Motamedi ${ }^{1,2 *}$, Soheyla Honary ${ }^{3}$, Iraj Kazeminezhad ${ }^{4}$. \\ ${ }^{1}$ Department of Biology, Faculty of Science, Shahid Chamran University of Ahvaz, Ahvaz, Iran. \\ ${ }^{2}$ Biotechnology and Biological Science Research Center, Shahid Chamran University of Ahvaz, Ahvaz, Iran. \\ ${ }^{3}$ Department of Pharmaceutical Science, Faculty of Pharmacy, Mazandaran University of Medical Science, Sari, \\ Iran. \\ ${ }^{4}$ Department of physics, Faculty of Science, Shahid Chamran University of Ahvaz, Ahvaz, Iran.
}

\begin{abstract}
Nanoparticles due to their unique properties have attracted more attention and their bacterial biosynthesis is more favorable because is environmental friendly and the size and yield of nanoparticles can be optimized. The aim of the present study was biosynthesis of Selenium nanoparticles using Bacillus cereus. For this purpose, bacterial culture was prepared in the presence of sodium selenate solution and incubated $\left(30^{\circ} \mathrm{C}, 24 \mathrm{~h}\right)$. The produced nanoparticles were purified through consequent centrifugation, washing with $0.9 \% \mathrm{NaCl}$, sonication, washing with $\mathrm{Tris}-\mathrm{HCl}$ containing Sodium dodecyl sulfate (SDS) and finally isolation with water-octanol two phase systems. Then using Ultraviolet-Visible spectroscopy, dynamic light scattering (DLS), scaning electron microscopy (SEM) and X-ray diffraction (XRD) analysis, nanoparticle production was confirmed. The bioavailability of nanoparticles was also investigated in rat. As a result of this study spherical selenium nanoparticles with a mean diameter of $170 \mathrm{~nm}$ were biosynthesized. MIC (minimum inhibitory concentration) and MBC (minimum bactericidal concentration) of selenium for Bacillus cereus were same and equal to $75 \mathrm{mM}$. Absorption and secretion of nanoselenium was significantly higher than bulk Selenium $(P<0.05)$. In conclusion in the present study without any chemical substance, spherical Selenium nanoparticles were produced that do not have any environmental contamination. Furthermore, the metabolism of these particles suggests higher absorption rate of them that facilitates its application in medicine and also veterinary medicine.
\end{abstract}

Key words: Bacillus cereus; Green chemistry; Selenium, nanoparticle.

\footnotetext{
*Author for correspondence: motamedih@scu.ac.ir, hhmotamedi@yahoo.com
} 
Pouri, S et al.

\section{INTRODUCTION}

Nanomaterials due to the size effect phenomenon have unique and new functions ${ }^{1}$. Increasing of surface to volume ratio leads to increase in function and reactivity of surface atoms ${ }^{1}$. Nanoparticles are made of several atoms or molecules with different size and morphology including spherical, layered, clustered, tube or rod shape ${ }^{1,2}$. Among nanoparticles, metallic and metalloid nanoparticles have been widely considered because of their catalytic, photo catalytic, absorbent, optical, electrical and magnetic applications. Top-down and bottom-up methods are two main approaches for nanoparticle synthesis ${ }^{3}$. In bottom- up method the product is made gradually by assembly of atoms ${ }^{4}$. In this procedure, that can be accomplished chemically or biologically, it is possible that atoms interactions be controlled ${ }^{5}$.The chemical method uses chemical stabilizers that leads to environmental pollution ${ }^{4}$. In contrast, biological synthesis of nanoparticles is superior because is a clean, cost effective, easy to operate and non-toxic approach which produces nanoparticles with novel properties. Microorganisms are of great importance with this respect ${ }^{3,6}$. Following encountering with metallic ions, microorganisms accumulate them inside cell or on cell wall with different methods that is finally leads to nanoparticle synthesis ${ }^{3}$. In the field of biological synthesis of nanoparticles, bacteria have been more focused due to their high resistance to metals and surviving under harsh environment. In this procedure, the size and yield of nanoparticle production can be optimized by adjusting $\mathrm{pH}$, temperature, substrate concentration and time of exposure to substrate 7 . Biosynthesis of gold and silver nanoparticles by Lactobalillus sp. and Bacillus sp. are two examples ${ }^{3,7}$.

Selenium (Se) is a metalloid element that is found with different oxidation status and properties in nature. It is commonly found as complexes with nutrient sulfides or Ag, $\mathrm{Cu}, \mathrm{Pb}$ and $\mathrm{Ni}^{8}$. This element which has photolytic and conductor properties, is applied in pesticides, glass industry and as food additive in animals and poultries meal ${ }^{9}$. It is a trace element found as selenomethionine, selenocysteine and also in a variety of enzymes ${ }^{10}$. In addition, it plays an important role in glutathione peroxidase system ${ }^{10,11}$ that in association with vitamin $\mathrm{E}$ can act as antioxidant for prevention of harmful effects of metabolites on tissues ${ }^{12,13}$. Furthermore, it is important in male fertility, immune system function, neurotransmitters production and prevention of malignancies in such a manner that its deficiency leads to multiple dysfunctions including thyroid dysfunction ${ }^{11,14-17}$. With regard to unique properties of selenium nanoparticles, their synthesis has been focused ${ }^{18}$. For this purpose different methods have been investigated. Liu et al (2004), have synthesized selenium nanoparticle by a reverse microemulsion system using sodium selenosulfate as selenium source. They found that hydrochloric acid concentration and reaction temperature have great influence on morphology of selenium nanoparticles ${ }^{19}$. Abdelouas et al (2000), produced selenium nanoparticles through application of cytochrome $\mathrm{C}_{3}$ obtained from Desulfovibrio vulgaris, a sulfate reducing bacterium. This cytochrome was able to reduce selenate to selenium and so production of selenium nanoparticles ${ }^{20}$. In the study of Zhang et al (2004) the reduction of selenium was performed by ascorbic acid in the presence of different polysaccharides such as chitosan, konjac glucomannan, acasia gum and carboxymethyl cellulose. Their results revealed that very stable spherical selenium nanoparticles were produced that are stable in solution for 6 months in the presence of polysaccharide ${ }^{21}$. However, in spite of different possible approaches for selenium nanoparticle production, its biosynthesis has been paid more attention because is an environmental friendly procedure ${ }^{22}$. The aim of the present study was biosynthesis of selenium nanoparticles using a selenium resistant bacterium and evaluating its absorption in mice. 


\section{MATERIALS AND METHODS}

\section{Isolation of selenium resistant bacterium}

The bacterial strain used in this study for selenium nanoparticle production was isolated from eastern pond of Imam Khomeini petrochemical industries complex, located in Mahshahr $\left(30.5589^{\circ} \mathrm{N}, 49.1981^{\circ} \mathrm{E}\right)$, khouzestan, Iran. This isolate was identified based on biochemical tests $f$ Bergey's manual of systematic bacteriology ${ }^{20}$ and confirmed by 16S rRNA gene sequencing. For this purpose, DNA was extracted from $48 \mathrm{~h}$ culture with DNA extraction kit (Cinagene, Iran) ${ }^{13}$. The Forward (5́CCGAATTCGTCGACAACAGAGTTTGATCCTGGCTCAG3́) and reverse primers (5́CCCGGGATCCAAGCTTACGGTTACCTTGTTACGACTT3́) were used for amplification of target gene in a reaction containing PCR buffer (1X), dNTPs $(10 \mathrm{mM}), \mathrm{MgCl}_{2}(2 \mathrm{mM})$, forward and reverse primers $(10 \mu \mathrm{M})$, Taq DNA polymerase $(1.5 \mathrm{U})$ and $3 \mu \mathrm{l}$ of template DNA in a final volume of $25 \mu 1^{13,24}$. Thermal cycling program was denaturation $\left(94^{\circ} \mathrm{C}, 60 \mathrm{~S}\right), 30$ cycles each including denaturation $\left(94^{\circ} \mathrm{C}, 60 \mathrm{~s}\right)$, annealing $\left(60^{\circ} \mathrm{C}, 40 \mathrm{~s}\right)$ and extension $\left(72^{\circ} \mathrm{C}, 150 \mathrm{~s}\right)$ and a final extension $\left(72^{\circ} \mathrm{C}\right.$ for $\left.20 \mathrm{~min}\right){ }^{13}$. The PCR product was evaluated by electrophoresis in $1 \%$ agarose gel containing DNA safe stain and subsequent sequencing (Macrogen, Korea).The sequence was compared in BLAST algorithm with available data in gene bank of NCBI.

\section{Minimum Inhibitory concentration (MIC) and Minimum Bactericidal concentration (MBC)}

For MIC and MBC determination, $100 \mu$ l of bacterial suspension with 0.5 McFarland turbidity was cultured in a series of $1 \mathrm{ml}$ Muller-Hinton broth (Merck, Germany) containing 0.5-1200 mM sodium selenate (Merck, Germany). A tube without sodium selenate was also regarded as control and all of them were incubated for $24 \mathrm{~h}$ at $30^{\circ} \mathrm{C}$ and $120 \mathrm{rpm}$. The first dilution in the mentioned series that didn't show any bacterial growth was regarded as MIC. A culture was subsequently prepared from those growth negative tubes on Muller-Hinton agar (Merck, Germany) in the absence of sodium selenate and incubated at $30^{\circ} \mathrm{C}$ for $24 \mathrm{~h}$. The least concentration that inhibited colony formation was considered as MBC. All of these experiments were repeated three times ${ }^{25}$.

\section{Growth curve}

The bacterial growth curve was obtained by inoculating nutrient broth (Merck, Germany) with $0.5 \mathrm{McFarland}$ bacterial suspension and incubation $\left(30^{\circ} \mathrm{C}, 120 \mathrm{rpm}\right)$. The absorbance of culture was recorded as triplicates at $600 \mathrm{~nm}$ every $2 \mathrm{~h}$ till $62 \mathrm{~h}$ of incubation ${ }^{9,24,26}$. In addition the growth curve was obtained in the presence of 0.5 , 1.75 and $3 \mathrm{mM}$ sodium selenate, according to the method described above.

\section{Production and isolation of selenium nanoparticles}

In order to find the best method for selenium nanoparticle production four treatments were designed. In fist two treatments, $1 \mathrm{ml}$ of fresh bacterial suspension $(0.5$ McFarland turbidity) was inoculated in two separate $100 \mathrm{ml}$ nutrient broth (Merck, Germany). For other two treatments, the two nutrient broth $(100 \mathrm{ml})$ was supplemented with sodium selenate solution $(100 \mathrm{mg} / \mathrm{ml})$ and only one of them was inoculated with $1 \mathrm{ml}$ of fresh bacterial suspension (0.5 McFarland turbidity). All flasks were incubated at $30^{\circ} \mathrm{C}$ for $24 \mathrm{~h}$. Then, one of the bacterial suspensions in 
nutrient broth (from the first two experiments) was centrifuged (15 min, 6000rpm), the harvested supernatant was mixed in 1: 1 ratio with sodium selenate solution (100 $\mathrm{mg} / \mathrm{ml}$ ) and incubated for further $24 \mathrm{~h}$ at $30^{\circ} \mathrm{C}$. Yellow to red color change was monitored in these experiments as an evidence for selenium nanoparticle production ${ }^{24}$. Based on the results of these experiments, the method of inoculation of nutrient broth containing $100 \mathrm{mg} / \mathrm{ml}$ sodium selenate with $1 \mathrm{ml}$ of $0.5 \mathrm{McFarland}$ bacterial suspension was selected for selenium nanoparticle production. So, in order to selenium nanoparticle production this suspension was prepared and incubated at 30 ${ }^{\circ} \mathrm{C}$ and $120 \mathrm{rpm}$ till reddish color change appearance, approximately, $24 \mathrm{~h}$, as an evidence for selenium nanoparticle production. After centrifugation (10 min, 5000 $\mathrm{rpm}$ ), the precipitate was washed with $0.9 \% \mathrm{NaCl}$ solution and then centrifuged at $5000 \mathrm{rpm}$ for $10 \mathrm{~min}$. Three consequent freeze and thaw $\left(-70\right.$ and $\left.40^{\circ} \mathrm{C}\right)$ were done. Final precipitate was dissolved in $5 \mathrm{ml}$ distilled water and sonicated. Following a centrifugation ( $5 \mathrm{~min}$ at $5000 \mathrm{rpm}$ ), the precipitate was washed three times with 1.5 $\mathrm{M}$ Tris $-\mathrm{HCl}(\mathrm{pH} \mathrm{8.3)}$ containing 0.5\% SDS (sodium dodecyl sulfate) for $10 \mathrm{~min}$ at $8000 \mathrm{rpm}$. In order to remove the remaining SDS, the precipitate that now contains selenium nanoparticles, was washed through three times dispersion in distilled water and centrifugation ( $8000 \mathrm{rpm}, 10 \mathrm{~min}$ ). Finally, the precipitate was resuspended in distilled water.

In order to purify selenium nanoparticles from cell debris, $4 \mathrm{ml}$ of prepared suspension was vigorously mixed with $2 \mathrm{ml}$ of octanol, centrifuged (5 min, 3000 $\mathrm{rpm})$ and incubated $\left(24 \mathrm{~h}\right.$ at $\left.4^{\circ} \mathrm{C}\right)$ for dissociation of two phases. In this manner, nanoparticles were accumulated in organic phase and impurities were remained in upper phase. The organic and aqueous phases were slowly separated and discarded and the remained nanoparticles were washed consequently with chloroform, absolute ethanol (Merck, Germany) and distilled water. These steps were repeated again in order to gain pure nanoparticles. The final suspension was stored at $4^{\circ} \mathrm{C}^{9,22,24,27}$.

\section{Nanoparticles assay}

In order to determine the size of nanoparticles, they were suspended in $5 \mathrm{ml}$ distilled water and sonicated $(5 \mathrm{~min})$. The Uv/Vis analysis in 400-600 $\mathrm{nm}$ was performed on the obtained suspension. Then the size of nanoparticles was determined with particle size analyzer (England, MALVERN INSTRUMENTS- ZEN3600). The shape of these nanoparticles was investigated with scaning electron microscopy (SEM). One $\mathrm{ml}$ of the above mentioned suspension was dried and coated with $\mathrm{Au}$ and then analyzed with SEM (Germany،LEO 1455 VP) of Shahid Chamran University of Ahvaz.

The XRD analysis was also performed for these nanoparticles with $\mathrm{x}$-ray instrument (France،NEL : EQuinox 3000) of Amir Kabir University ${ }^{28}$.

\footnotetext{
Absorption of nano-selenium and bulk selenium in vivo

In order to determine the stability of produced selenium nanoparticles and also the effect of nano scale on its biological absorption in comparison with bulk selenium, its absorption was evaluated in mice. 24 female rats ( 220 gr average) were grouped in to 3 groups of 8 members and $100 \mathrm{\mu gr} / \mathrm{Kg}$ of nano-selenium, bulk sodium selenate and distilled water were injected intra-peritoneal (IP) in to first, second and third groups, respectively. Blood samples then collected at $24 \mathrm{~h}$ and $48 \mathrm{~h}$ after injection ${ }^{29-}$ 31 . These samples were centrifuged ( $5 \mathrm{~min}, 2000 \mathrm{rpm}$ ) and $500 \mu \mathrm{l}$ of serum was collected ${ }^{30}$. The serum samples were diluted in $1: 2$ ratios with $0.1 \%$ nitric acid (v/v) plus $0.1 \%$ Triton- X100 and their selenium concentration were measured using atomic absorption spectroscopy ${ }^{32}$.
} 


\section{RESULTS}

The results of biochemical tests and also 16S rRNA sequencing revealed that the bacterial isolate is Bacillus cereus which named as B. cereus BIPC04 (Fig 1).

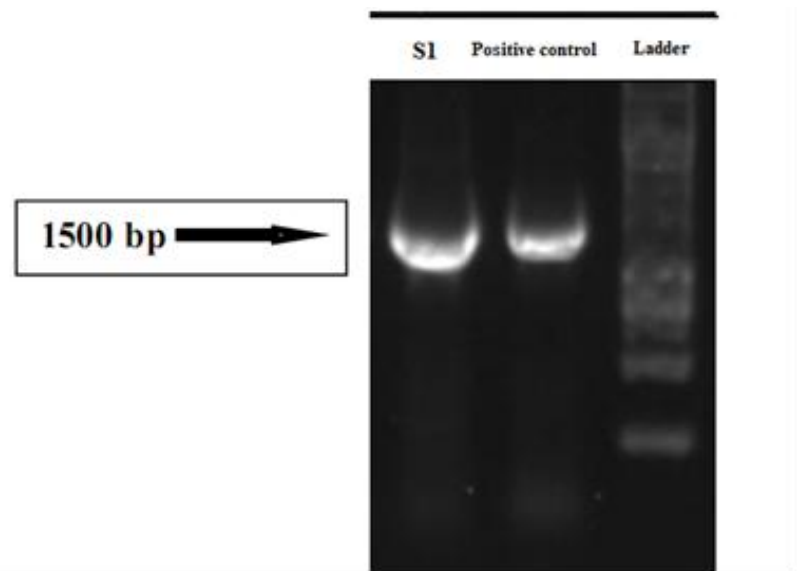

Figure1.Electrophoresis of $16 \mathrm{~S}$ rRNA PCR product. 1500 bp product was amplified from B. cereus BIPC04

This isolate had $99 \%$ identity with registered B. cereus sequences in gene bank of NCBI. In the experiment for MIC and MBC, the yellow to red color change was obvious till $37.5 \mathrm{mM}$ of sodium selenate but not in higher concentrations. As a result of culturing from higher concentrations on nutrient agar no bacterial growth and colony formation was happened. So the MIC and MBC of selenium for this bacterium was $75 \mathrm{mM}$ (Fig 2).

In growth curve analysis, $2 \mathrm{~h}$ after challenging the bacterium with $0.5 \mathrm{mM}$ selenate, color change from yellow to orange-red was appeared that is a clue for selenate reduction to selenite and finally selenium. As we can find in (Fig 3), the isolate had much growth in the absence of sodium selenate and its growth curve was higher than when it encountered to $0.5 \mathrm{mM}$ concentration of sodium selenate. This shows the effect of selenium on bacterium. However, in the 1.5 and $3 \mathrm{mM}$ concentrations treatments, the higher growth curves were obtained for this bacterium. This higher absorbance do not means that this isolate had higher growth in 1.5 and $3 \mathrm{mM}$ sodium selenate but is related to the color change and this fact that the absorption spectrum of orange color is in the $585-620 \mathrm{~nm}$. So, the absorbance in these treatments were higher than control as well as $0.5 \mathrm{mM}$ treatment.

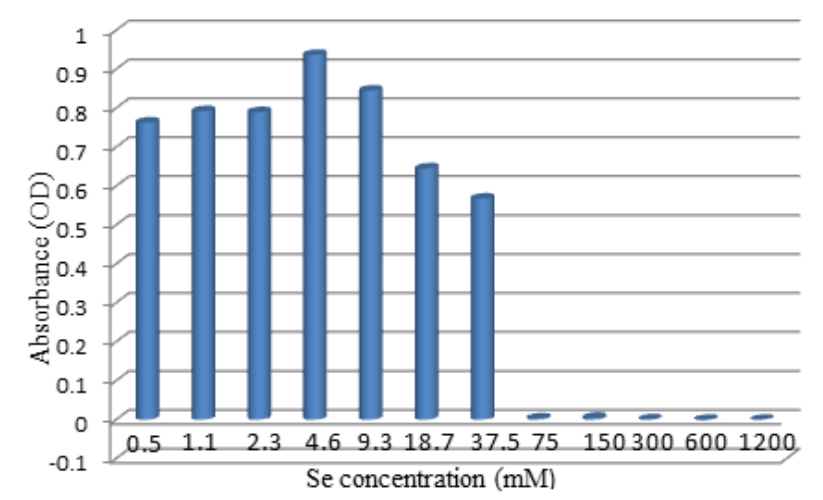

Figure 2.Growth of B. cereus in different concentrations of Se. The growth was inhibited at $75 \mathrm{mM}$ concentration 


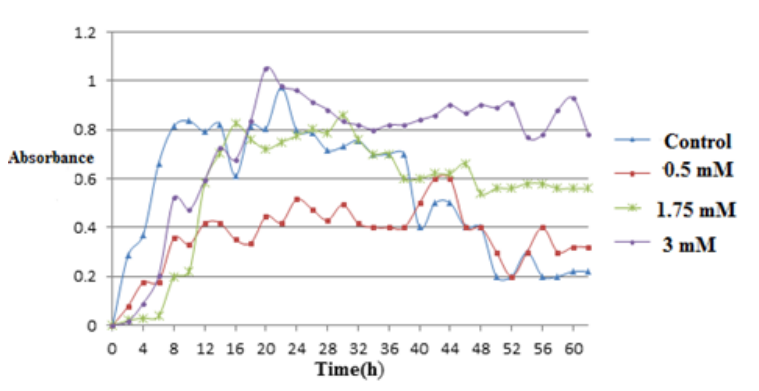

Figure 3.B. cereus BIPC04 growth curve $(600 \mathrm{~nm})$ in the presence and absence of sodium selenite.

Produced selenium nanoparticles have been evaluated by different methods. At $\mathrm{Uv} / \mathrm{V}$ is analysis in $400-600 \mathrm{~nm}$, the absorption peak was obtained at $420-450 \mathrm{~nm}$ that is related to selenium nanoparticle (Fig 4).

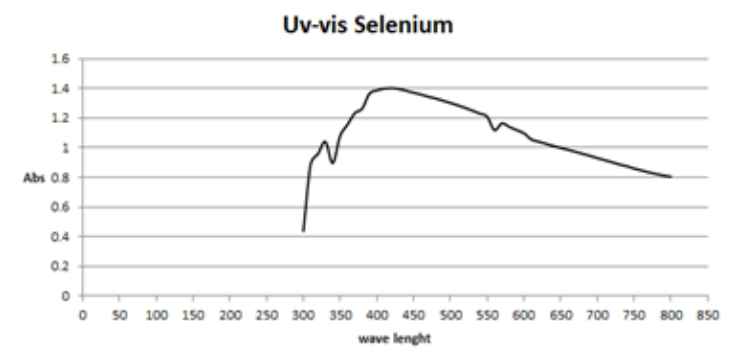

Figure 4.Uv/Vis analysis of produced Se nanoparticles.

The result of XRD analysis was in accordance with standard spectrum of selenium nanoparticle that confirms selenium nanoparticle production (Fig5).

The mean size of these nanoparticles was calculated by Deby- sharer equation (1):

$$
\mathrm{D}=0.9 \lambda / \beta \operatorname{Cos} \theta
$$

According to this equation the $35.5 \mathrm{~nm}$ was obtained for the mean size of selenium nanoparticles [30]. The SEM results revealed that symmetrical and spherical nanoparticles were produced (Fig 6). Due to long time for purifying nanoparticles, it is possible that nanoparticle growth has been happened.

Table I presents the results of selenium absorption in mice. In control group no measurable concentration of selenium was present while in two test groups selenium was obviously measured at 24 and $48 \mathrm{~h}$ after injection. As it can be found, the serum level of seleniumin nano group was significantly $(\mathrm{p}<0.029)$ higher than bulk selenium group (Fig 7). One way variance analysis revealed significant difference between 3 groups. The results suggests that after 24h, absorption of selenium nanoparticles were higher than bulk selenium. Furthermore, the excretion rate of selenium was also higher in the group received seleniumnanoparticles.

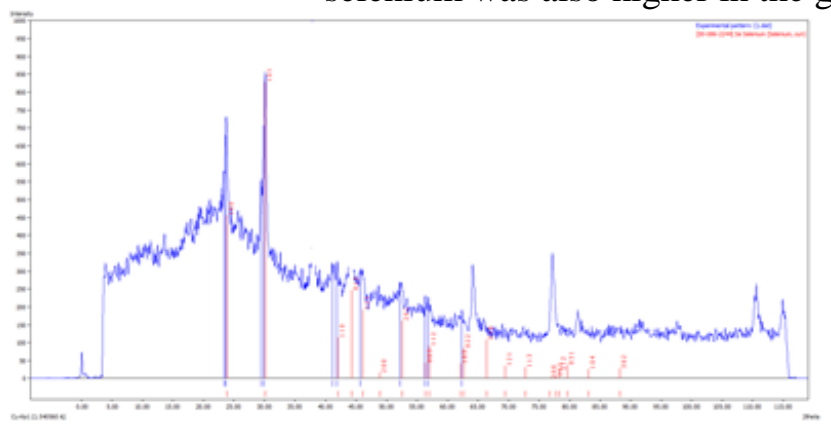

Figure 5.XRD analysis of biologically produced Se nanoparticles. These data are in accordance with standard X-ray diffraction (JCDPS: 00-086-2244) 
Selenium nanoparticle biosynthesis

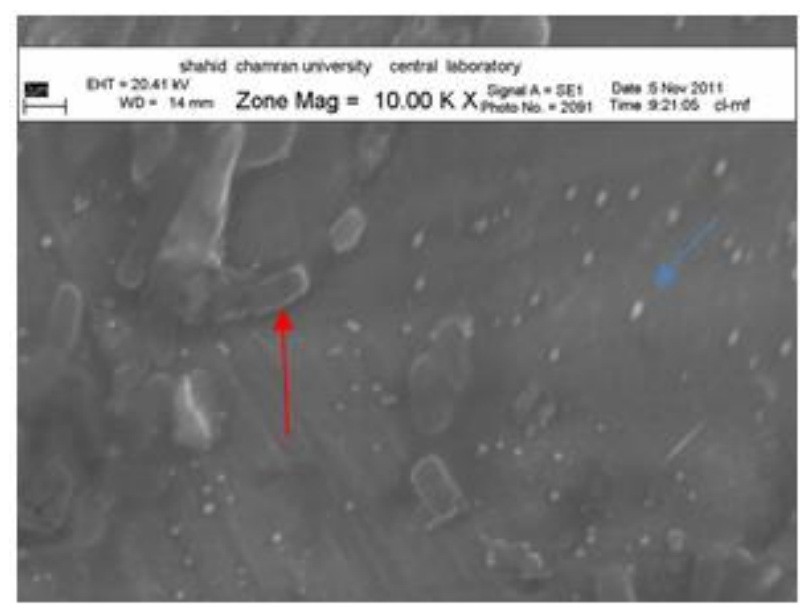

Figure 6(a). Se nanoparticles (blue arrow) before purification with aqueous/ organic biphasic method. Red arrow indicates bacterial debris.

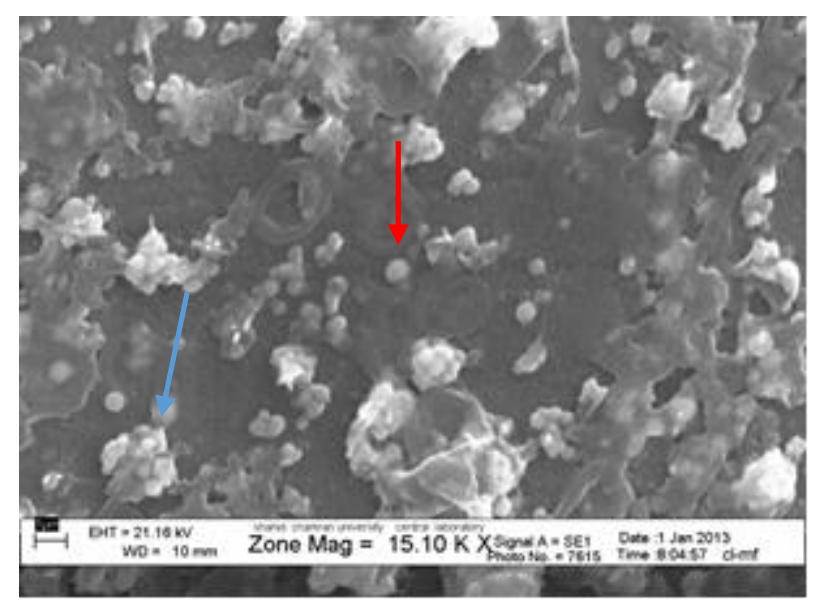

Figure 6 (b).Se nanoparticles after purification with aqueous/ organic biphasic method. Red arrow is Se nanoparticle and blue arrow shows their aggregation.

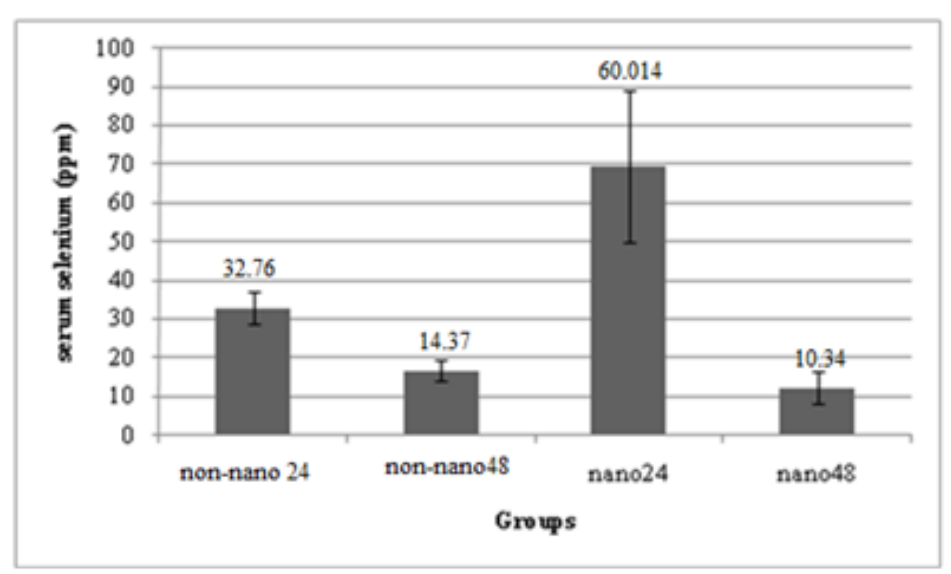

Figure 7. Bulk Se and nano Se concentrations in the serum of female wistar rat 
Table I. Se concentration in the serum of female wistar rat.

\begin{tabular}{|l|l|l|l|l|}
\hline Control (ppm) & \multicolumn{2}{|l|}{ Bulk Se concentration (ppm) } & \multicolumn{2}{l|}{ Nano Se concentration (ppm) } \\
\hline- & $\mathbf{4 8}(\mathbf{h})$ & $\mathbf{2 4 ( h )}$ & $\mathbf{4 8 ( h )}$ & $\mathbf{2 4 ( h )}$ \\
\hline- & 12.73 & 29.52 & 20.29 & 17.71 \\
\hline- & 21.90 & 70.14 & 17.33 & 100.23 \\
\hline- & 15.19 & 43.41 & 2.59 & 74.52 \\
\hline- & 7.66 & 27.62 & 18.12 & 74.52 \\
\hline Average & 14.37 & 32.67 & 10.34 & 60.014 \\
\hline
\end{tabular}

\section{DISCUSSION}

Microorganisms have oxido-reductive systems in order to use metals and also regulate their concentrations. This happen through altering metal charge that is accomplished by membrane electron transport system and reductive enzymes. In this manner, microorganisms can regulate metal ions diffusion and detoxify them ${ }^{34}$. Selenate can be metabolized through two possible metabolism pathways: dissimilatory selenate reduction that produces elemental selenium and assimilatory selenate reduction that leads to volatile selenium ${ }^{35}$. Two present allotropes of selenium in soil are red and black. selenium (0) in aqueous solution has red appearance and in temperature higher than $45^{\circ} \mathrm{C}$ it gradually becomes black ${ }^{36}$. The final products of dissimilatory reactions in different bacterial species are red and black allotropes that accumulates in medium ${ }^{37}$.

Bacillus cereus BIPC04 that has been used in the present study due to gram positive cell wall structure and also spore formation is a good option for selenium nanoparticle production especially with regard to its resistance to selenium. Selenate is reduced in a two consequent steps from selenate to selenite and then elemental selenium. In the growth curve of B. cereus BIPC04 the color change was appeared at $2 \mathrm{~h}$ that led to higher absorption at $600 \mathrm{~nm}$. This confirms selenium nanoparticle production $^{9,22,24,38,39}$.

Bacillus cereus BIPC04 was resistant to $0.5-37.5 \mathrm{mM}$ concentration of sodium selenate with MIC and MBC equal to $75 \mathrm{mM}$. Yadav et al (2008) and Anand et al (2005) reported the appearance of red color after $12 \mathrm{~h}$ of bacterial culture (Pseudomonas aeruginosa) in a broth containing selenium and regarded it as a reason for selenium $(0)$ production.

Pseudomans stutzeri has been reported in the study of Lorti et al (1992) that was able to tolerate $2.53 \mathrm{mM}$ of sodium selenite ${ }^{40}$. Kessi et al (1999) reported the maximum tolerance to selenium for Rhodosprillium rubrum as $1.5 \mathrm{mM}^{36}$. In the study of kashiwe et al (2000), Bacillus sp. was able to reduce $20 \mathrm{mM}$ selenate to selenite and $2 \mathrm{mM}$ of selenite to elemental selenium but the reduction rate of selenate was higher ${ }^{41}$. Roux et al (2001) reported that Ralstonia metallidurans can tolerate $6 \mathrm{mM}$ selenite and reduce it to selenium (0). Zahir et al (2003) isolated Enterobacter taylorae from rice farm drainage that was able to grow at $500-5000 \mathrm{\mu gr} / 1$ of selenate in such a manner that reduced $81-94 \%$ of it during five days ${ }^{42}$. As it can be found $B$. cereus BIPC04 that has been used in this study can tolerate and metabolize higher concentrations of selenate than the reported for other bacteria in similar researches. However, in the study of Yadav et al (2008), Pseudomonas aeruginosa SNT1 isolated from soil was able to grow at $50 \mathrm{mg} / 1{ }^{37}$ that is more than the tolerance of B. cereus BIPC04 but, with regard to the ability of spore formation 
in B. cereus BIPC04, it can be considered as an advantage of the present study in comparison to the mentioned one.

In XRD analysis, hexagonal structures without amorphous shapes were found and the presence of prominent peaks in this spectrum reveals the high degree of nanoparticle crystallization. No peak that suggests impurity was present. The SEM analysis also showed symmetric and spherical nanoparticles.

$B$. cereus BIPC04 following to the changing the growth parameters was able to produce intracellular spherical Se nanoparticles with mean diameter of $170 \mathrm{~nm}$. These nanoparticles were stable in the absence of any chemical stabilizer even after injection to rat. This stability is of great importance in medicine and pharmaceutical products production.

Shakibaei et al (2010), have produced intracellular selenium nanoparticles using Bacillus sp. Msh1, an isolate from Caspian sea, with 142- $255 \mathrm{~nm}$ in size but transmission electron microscopy (TEM) revealed spherical nanoparticles with 80$220 \mathrm{~nm}$ that had maximum absorbance at $450-500 \mathrm{~nm}$ in Uv/Vis analysis and confirmed by XRD analysis ${ }^{24}$. Debieux et al (2011), have produced spherical (150 $\mathrm{nm}$ ) selenium nanoparticles using Thauera selenatis and confirmed it only by TEM analysis ${ }^{39}$. Dhanjal and Cameotra (2010), isolated B. cereus CM100B from soil that was able to produce intra- and extracellular selenium nanoparticles with $150-200$ $\mathrm{nm}$ mean diameter based on TEM analysis. These nanoparticles had maximum absorbance at $590 \mathrm{~nm}^{22}$. Lee et al (2007), reported that Shewanella sp. HN-41 is able to reduce selenium (IV) during respiration and produce selenium nanoparticles with $164-181 \mathrm{~nm}$ size ${ }^{38}$.

The results of seleniumabsorption in mice revealed that the rate of selenium nanoparticle absorption in first $24 \mathrm{~h}$ and its excretion at second $24 \mathrm{~h}$ is higher than bulk selenium. Therefore nano-selenium due to having higher absorption and excretion rate has less toxicity than bulk selenium. This has a significant effect in reducing the injection dose of selenium drugs and also hepatic and renal damages resulting from this element. Zhang et al (2005) have studied the toxicity of bulk selenium and selenium nanoparticles on rat liver. Their results revealed that selenite had increased the serum level of alanine aminotransferase and aspartate aminotransferase and inhibited the activity of catalase and superoxide dismutase while had no effect on these enzymes. Furthermore, selenite caused increase in liver malonaldehyde and seleniumnanoparticles decreased it. Both of them had same effect on glutathione peroxidase activity ${ }^{31}$. Benko et al (2012) studied the toxicity of selenium containing compounds in mice through treating mice with different selenium compounds and concentrations. As a result, they reported that maximum selenium accumulation was happened in liver and spleen of mice ${ }^{43}$. In the study of Chiba et al (1987), it was suggested that selenium and Sn have maximum accumulation in bone, liver and spleen of mice. ${ }^{29}$

\section{CONCLUSION}

In the present study using B. cereus BIPC04 and without any chemical substance, spherical selenium nanoparticles with mean diameter of $170 \mathrm{~nm}$ were produced that is preferable than chemical methods and have no environmental contamination. Furthermore, the metabolism of these particles suggests higher absorption rate that facilitates its application in medicine and also veterinary medicine. 


\section{ACKNOWLEDGMENTS}

The author wish to thanks vice chancellor for research of Shahid Chamran University of Ahvaz in aspect of providing research grant (Grant No: 874095) and also MSc. thesis grant. We also thanks Dr. Hossein Najafzadeh for kindly helps in In vivo experiments.

\section{REFERENCES}

1 Y., Fukumroi, Adschiri, et al: Structural control of nanoparticels, In K., Nogi, M., Hosokawa, M., Naito, T.,Yokoyama. (Eds):' Nanoparticle Technology Handbook' ( Elsevier, 2012, $2^{\text {nd }}$ edn), pp. 49-112.

2 L., SoSa, C., Noguez, R.G., Barrera.: Optical properties of metal nanoparticles with arbitrary shapes`, J. Phys Chem, 2003, 170, (26), pp. 6269-6275.

3 K., Badari, N.,Sakthivel.: 'Biological synthesis of metal nanoparticle by microbes', $A d v$ Colloid Interface Sci, 2010, 156, (1-2), pp. 1-13

4 R., Masala.: 'Synthesis routes for large volumes of nanoparticles`, Ann Rev Mater Res, 2004, 43, (1), pp 41-81.

5 T., Suzuki.: 'Mechanochemical synthesis of nanoparticles`, J Mater Sci, 2004, 39, (16), pp 5143-5146.

6 N., Kannan, S., Subbalaxmi.: 'Biogenesis of nanoparticles a current perspective ', Rev Adv Mater Sci, 2011, 27, (1), pp 99-114.

7 B., Nair, T., Pradeep.: 'Coalescence of nanoclusters and formation submicron crystallites assisted Lactobacillus strains`, J Crystal Growth, 2002, 2,(4), pp 293-298.

8 HM., Ohlendorf.: Ecotoxicology of Selenium, In Hoffman, D.J., Rattner, B.A., Burton, G.A., Cairns, J. (Eds): 'Handbook of Ecotoxicology' (Lewis Publishers, 2003, $2^{\text {nd }}$ edn), pp 465-500.

9 P., Jafari fesharaki, P., Nazari, M., Shakibaie, S., Rezaie, M., Abdollahi, AH., Shahverd.: Biosynthesis of selenium nanoparticles using Klebsiella pneumoniae and their recovery by simple strerilization process`, Brazilian J Microbiol, 2010, 2,(41), pp 461-466.

10 H., Wang, J., Zhang, H., Yu.: Elemental selenium at nano lower toxicity without compromising the fundamental effect on selenoenzymes: comparsion with selenomethionine in mice', Free Radical Biol Med, 2007, 42, (10), pp 1524-1533.

$11 \mathrm{H}$., Zeng.: `Selenium as an essential Micronutrient: Roles in cell cycle and apoptosis`, Mol, 2009, 14, (1), pp 1263-1278.

12 JF., Stolz, DJ., Ellis, JS., Blum, D., Ahmann, DR., Lovley, RS., Oremland. : Sulfurosprillium barnessi sp.nov.and Sulfurosprillium arsenophilum sp. Nov. new members of the Sulfurosprillium clade of the Proteobacteria', Int J Syst Bacteriol, 1999, 3,(49), pp 1177-1180.

13 WG., Weisburg, SM., Borns, DA., Pelltier, DJ., Lane.: 16s Ribosomal DNA amplification for phylogenetic study', J Bacteriol, 1991, 173,(6), PP 697-703.

14 L., Letavayova, V., Vlckova, J., Brozmanova.: Selenium: from prevention to DNA damage , Toxicology, 2006, 227,(1), PP 1-14.

15 MB., Saad, LR., Gertner, TD., Bona, E., Santin.: Selenium influence in the poultry immune response review`, Recent Pat Food Nutr Agric, 2009, 1,(3), pp 243-247.

16 MP., Rayman.: Food- chain selenium and human health: emphasis on intake', British J Nutr, 2008, 100,(2), pp 254-268.

17 T., Klaus - Joerger, R., Joerger, E., Olsson, C.,Granquist.: Bacteria as workers in the living factory: Metal-accumolating bacteria and their potential for materials science, Biotechnol, 2001, 19,(11), pp 15-20.

18 LB., Yang, YH., Shen, Liang JJ., Xie AS, , BC., Zhang.: `Synthesis of Se nanoparticles by using TSA ion and it is photocatalytic application for decolorization of cango red under UV irradiation, Mater Res Bull, 2008, 43, (1), pp 572-582.

19 MZ., Liu, Sy., Zhang, Y.H., Shen, and M.L., Zhang.: Selenium nanoparticles prepared from reverse microemulsion process, Chin Chem Lett, 2004,15, (10): pp1294-1252.

20 A., Abdelouas, WL.,Gong, W., Lutze, JA., Shelnutt, R., Franco and I., Moura.: Using cytochorome C3 to make selenium nanowires. Chem Mater, 2000,12, (6):pp1510-1512. 
21 Sy., Zhang, J., Zhang, Hy., Wang and Hy., Chen.: Synthesis of selenium nanoparticels in presence of polysaccharides. Mater Lett, 2004, 58, (21): pp2590-2594.

22 S., Dhanjal, S., Cameotra.: Aerobic biogenesis of selenium nanospheres by Bacillus cereus isolated from coalmin soil, Microb cell Factories, 2010, 9, (52), pp 1-11.

23 W.B., Whitman.: Bergey's Manual of Systematic Bacteriology( Springer, 2009, 2nd ed, Vol 3), pp 21- 128.

24 M., Shakibaie, MR., Khorramizadeh, MA., Faramarzi, O., Sabzevari, AM., Shahverdi.: Biosynthesis and recovery of selenium nanoparticles and the effects on matrix metalloproteinase-2 expression ', Biotechnol Appl Biochem, 2010,56,(1), pp 7-15.

25 S., Sarker , L., Nahar, Y., Kumarasamy.: Microtitre plate-based antibacterial assay incorporating resazurin as an indicator of cell growth, and its application in the in vitro antibacterial screening of phytochemicals', Natural Product Research: The Challenges Facing the Modern Researcher, 2007,42,(4), pp 321-324.

26 E., Dumon.: Hyphenated techniques for speciation of Se in biological matrices. Gent . PhD. Thesis, GENT university, 2006.

27 S., Khademi Mazdeh, H., Motamedi, A., Akbarzadeh Khiavi, MR., Mehrabi.: Gold Nanoparticle Biosynthesis by E. coli and Conjugation with Streptomycinand Evaluation its Antibacterial Effect, Curr Nano, 2014, 4, (10), pp 553- 561.

28 PS., Hale, J., Chem.: 'Materials and Experimental Techniques' In: Experimental Techniques for material Characterization, (CRC Press, 2005, 1st edn), pp. 61-74

29 M., Chiba, N., Kamiya, M., Kikuchi.: Experimental study on interaction between Selenium and Tin in mice. Biol Trace Elem Res. 1987; 15(2):289-301.

30 F., Cuparigova, T., Stafilov.: Determination of selenium in human blood serum by electrothermal atomic absorption spectrometry`, Chem Sci J, 2011, 46,(1), pp 1-8.

31 J., Zhang, H., Wang, Y., Xiangxue, 1., Zhang.: Comparison of short-term toxicity between nano-Se and selenit in mice , Life Sci, 2005, 76,(10), pp 1099-1109.

32 M., Inomota, Y., Yagi, M., Saito, S., Saito.: Density dependence of the molar absorption coefficient application of the beer-lamber law to supercritical $\mathrm{co}_{2}$ - Naphthalene mixture , $J$ Supercrit Fluids, 1993, 6, (4), pp 237-240.

33 A., Hyo-Jin, Ch., Hyun-Chul, P., Kyung-Won, K., Seung-Bin, S.,Yung-Eun.: Investigation of the Structural and Electrochemical Properties of Size-Controlled SnO Nanoparticles, J. Phys Chem, 2004,108, pp 9815-9820.

34 B., Munner.: Role of microorganism in remediation of heavy metals in the wastewater of tanneries . MS.thesis, University of the Punjab, Quaid-i-Azam campus, 2005.

35 R., Turpeinen.: Interaction between metals, microbes and plants bioremediation of arsenic and lead contaminated soil . MS.thesis, University of Helsinki, 2002.

36 J., Kessi, M., Ramuz, E., Wehrli, M., Spycher, R., Bachofen.: Reduction of selenite and detoxification of elemental selenium by phototrophic bacterium Rhodosprillium rubrum, Appl Environ Microbiol, 1999, 11, (65), pp 4734-4740.

37 V., Yadav, N., Sharma, R., Prakash, K., Riia, LM., Bharadway, N., Tejoprakash.: Generation of selenium containing nano-structures by soil bacterium Pseudomonas aeruginosa , Biotechnol, 2008, 2,(7), pp 299-304.

38 JH., Lee, J., Han, H., Choi, HG., Hur.: Effect of temperature and dissolved oxygen on Se (IV) removal and Se (0) precipitation by Shewanella sp. HN-41, Chemosphere. 2007, 68, (10), pp 1898-1905.

39 C., Debieux, E., Dridgea, C., Mueller, P., Splatt.: A bacterial process for selenium nanosphere assembly , Proc Natl Acad Sci, 2011,108, (33), pp 13480-13485.

40 L., Lortie, WD., Gould, S., Rajan, RG., Meeready, KJ., Cheng.: Reduction of selenate and selenite to elemental selenium by Pseudomonas stutzeri isolate, Appl Environ Microbiol, 1992, 12, (58), pp 4042-4044.

41 M., Kashiwa, S., Ishimoto, K., Takahashi, M., Ike, M., Fujita.: Factors affecting soluble selenium removal by a selenate-reducing bacterium Bacillus sp. SF-1', Biosci Bioeng, 2000, $89,(6)$, pp 528-533.

42 Z., Zahir, Y., Zhang, T., William, JR., Frankenberger.: Fate of selenate metabolized by Enterobacter taylorae isolated from Rice Straw', Agric Food Chem, 2003, 12, (51), pp 36093613. 
43 I., Benko, G., Nagy, B., Tanczos et al: Subacute toxicity of nano-selenium compared to other selenium species in mice', Environ toxology, 2012, 31, (12), pp 2812-2820.

Received: February 03, 2016; Accepted: July 14, 2016 